\title{
Massive occurrence of Podagrica fuscicornis (L.) (Coleoptera, Chrysomelidae) on common marshmallow (Althaea officinalis L.)
}

\author{
Tanja BOHINC ${ }^{1}$, Matej VIDRIH ${ }^{2}$, Stanislav TRDAN ${ }^{3}$
}

Received August 11, 2011, accepted September 16, 2011.

Delo je prispelo 11. avgusta 2011; sprejeto 16. septembra 2011.

\begin{abstract}
In May 2011 we noticed high number of Podagrica fuscicornis adults on the leaves of common marshmallow (Althaea officinalis) grown on Laboratory Field of Biotechnical Faculty in Ljubljana. In Slovenia, this beetle was already recorded earlier but it did not caused any damage on common marshmallow (Althaea officinalis). Due to the feeding of beetles on leaves, 1 to $2 \mathrm{~mm}$ large holes appear. By expecting climate changes, already known bionomics of some related species and giving more emphasis on herb production in the future, Chrysomelid $P$. fuscicornis might represent medium sized biological factor in producing common marshmallow.
\end{abstract}

Key words: flea beetles, Podagrica fuscicornis, medicinal plants, common marshmallow, Althaea officinalis

\section{IZVLEČEK}

MOČAN POJAV VRSTE Podagrica fuscicornis (L.) (Coleoptera, Chrysomelidae) NA NAVADNEM SLEZU (Althaea officinalis L.)

V maju 2011 smo na listih navadnega sleza (Althaea officinalis) na Laboratorijskem polju Biotehniške fakultete $\mathrm{v}$ Ljubljani ugotovili večje število odraslih osebkov bolhača Podagrica fuscicornis. Vrsta je bila v Sloveniji že prej zastopana, a ni bila škodljiva pri pridelovanju navadnega sleza (Althaea officinalis). Na listih rastlin se kot posledica hranjenja hroščev pojavijo 1-2 mm velike luknjice. $\mathrm{Ob}$ pričakovanih podnebnih spremembah, znani bionomiji nekaterih sorodnih vrst in večjem pomenu pridelave zelišč v Sloveniji bi lahko vrsta $P$. fuscicornis v prihodnosti bila srednje pomemben biotični dejavnik pri pridelavi navadnega sleza.

Ključne besede: bolhači, Podagrica fuscicornis, zdravilne rastline, navadni slez, Althaea officinalis

\section{INTRODUCTION}

In Europe herbal plants production is taking place on land area of around 120,000 hectares and utilisation of medicinal plants, flavour and aromatic plants, spices and herbs for special purposes (natural pigments, antioxidants etc.) is becoming an important category of agricultural production. Slovenia is among those countries which do not have any particular tradition in medicinal plant production. In Flora of Slovenia there are 3216 species which are registered as higher plants and almost $12 \%$ are less or more used as medicinal or aromatic plants. According to survey data from 2004 medicinal plants are grown on 20 to 25 hectares in Slovenia (Rode and Knapič, 2006), and afterwards their production extent decreased (Statistični urad RS, 2011).

Flea beetles are members of family leaf beetles (Chrysomelidae) and occur in all vegetation habitats. Palaearctic species occur most frequently in the open, namely in the vicinity of grasslands, forests and water bodies (Gruev and Döberl, 1997; Çilbiroglu and Gok, 2004). Only some of these species cause damage on cultivated or native plants permanently or on occasions.

1 B. Sc., Zgornja Lipnica 9a, SI-4246 Kamna Gorica, e-pošta: tanja.bohinc@gmail.com

2 Assist. Prof., PhD., Biotechnical Faculty, Dept. of Agronomy, Chair of Phytomedicine, Agricultural Engineering, Crop Production, Pasture and Grassland Management, Jamnikarjeva 101, SI-1111 Ljubljana

3 Assoc. Prof., PhD., ibid. 
In the following paper we want to introduce the species of flea beetles, which is a typical member of subfamily Alticinae, but in contrast to some other related species flea beetles (Phyllotreta spp.) (Brelih et al., 2003) or hop flea beetle (Psylliodes attenuatus [Koch] (Brelih et al., 2003; Rak Cizej and Milevoj, 2007) - not yet presenting special danger in plant production. In 2011 we noticed on common marshmallow a massive occurrence of adult beetles which fed on leaves and flowers and consecutively evoke typical symptoms spherical and oblong hollows.

\section{MATERIALS AND METHODS}

In May 2011 we noticed during the survey of occurrence of pest organisms on herbal plants on Laboratory Field of Biotechnical Faculty, hollows on leaves of common marshmallow. The hollows were characteristical for representatives of Chrysomelidae family. On leaves (Figures 1

and 2) we found larger number of beetles, which were determined as Podagrica fuscicornis (Linnaeus, 1767) according to morphological characters. During the monitoring in July we noticed that the adults feed also on flowers of common marshmallow (Figure 3).

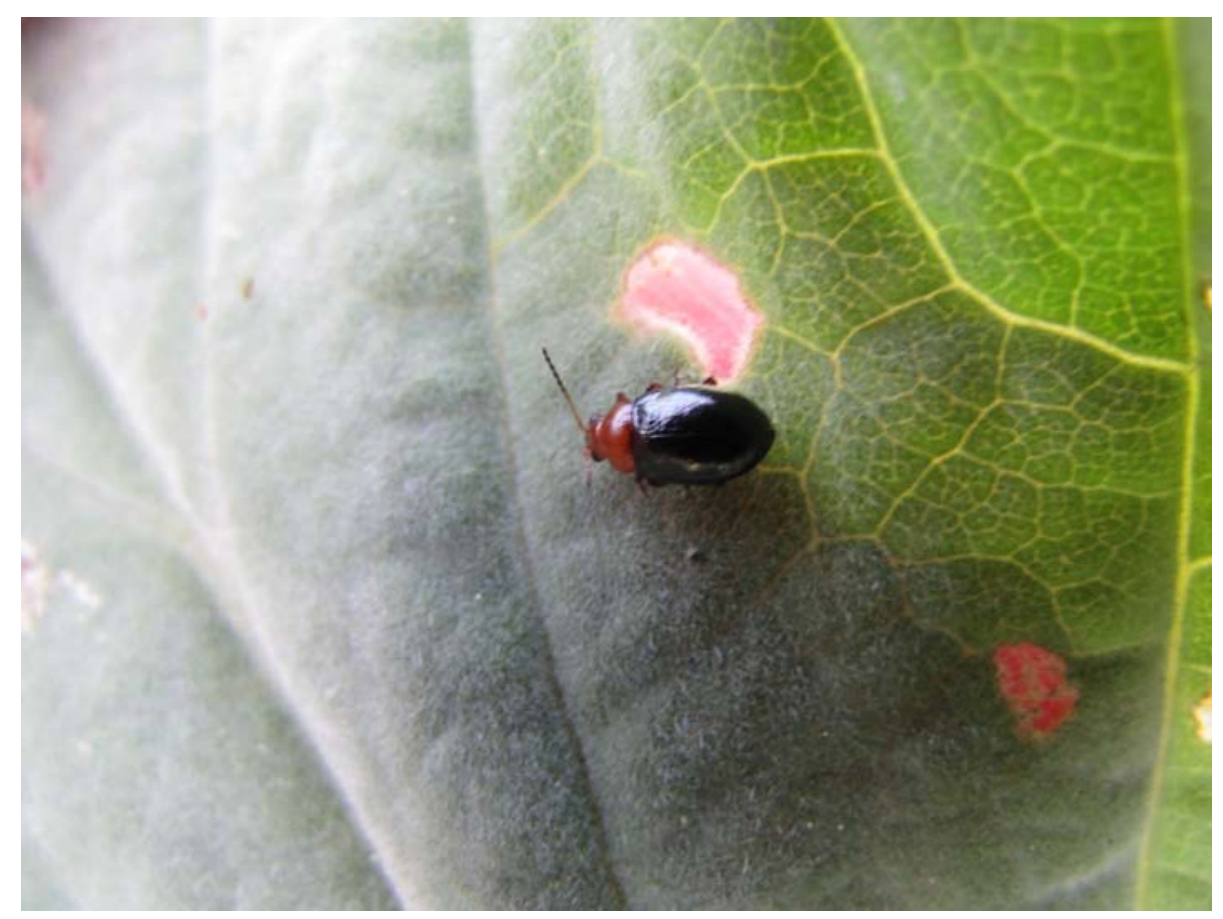

Figure 1: Flea beetle Podagrica fuscicornis and damage spots made because of its feeding on leaf of common marshmallow (photo by T. Bohinc) 
Massive occurrence of Podagrica fuscicornis (L.) (Coleoptera, Chrysomelidae) on common marshmallow ...

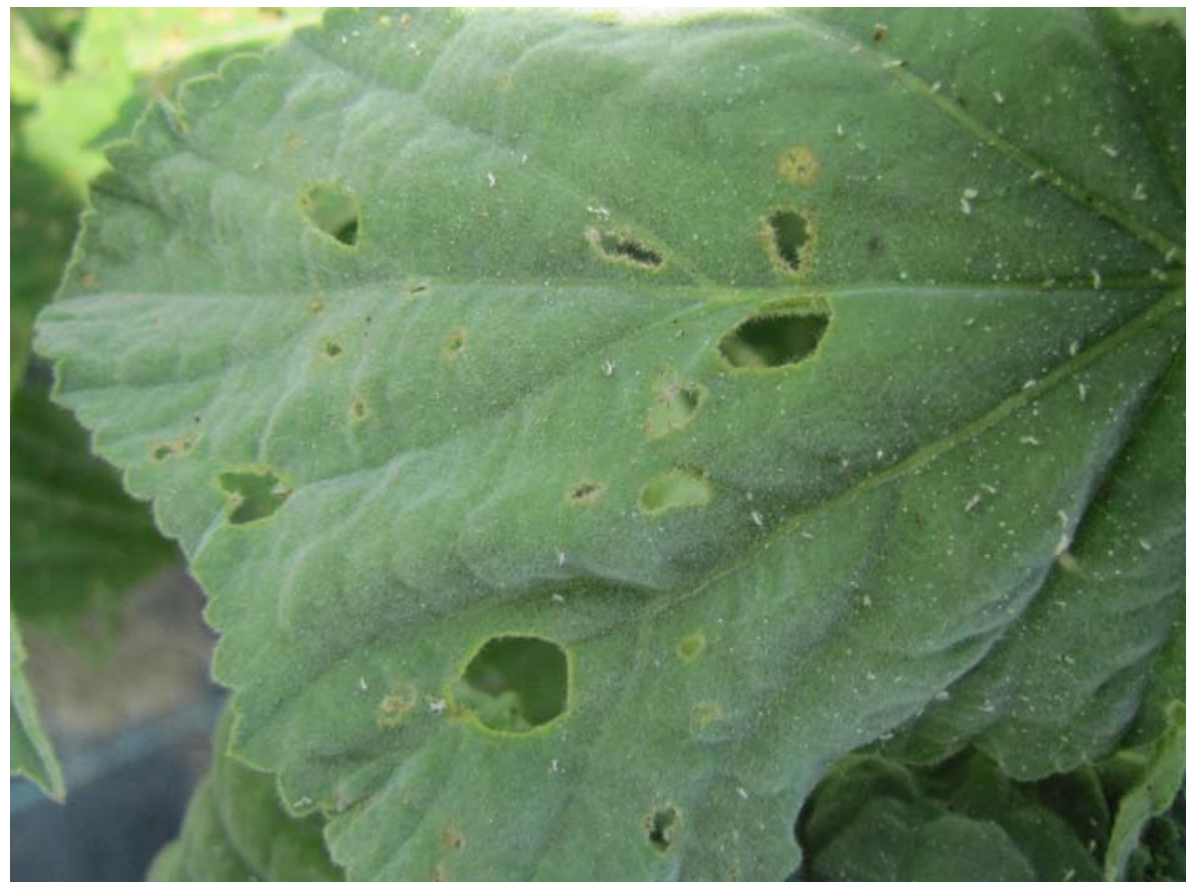

Figure 2: Damage on the leaf of common marshmallow due to the feeding of Podagrica fuscicornis adults (photo by T. Bohinc)

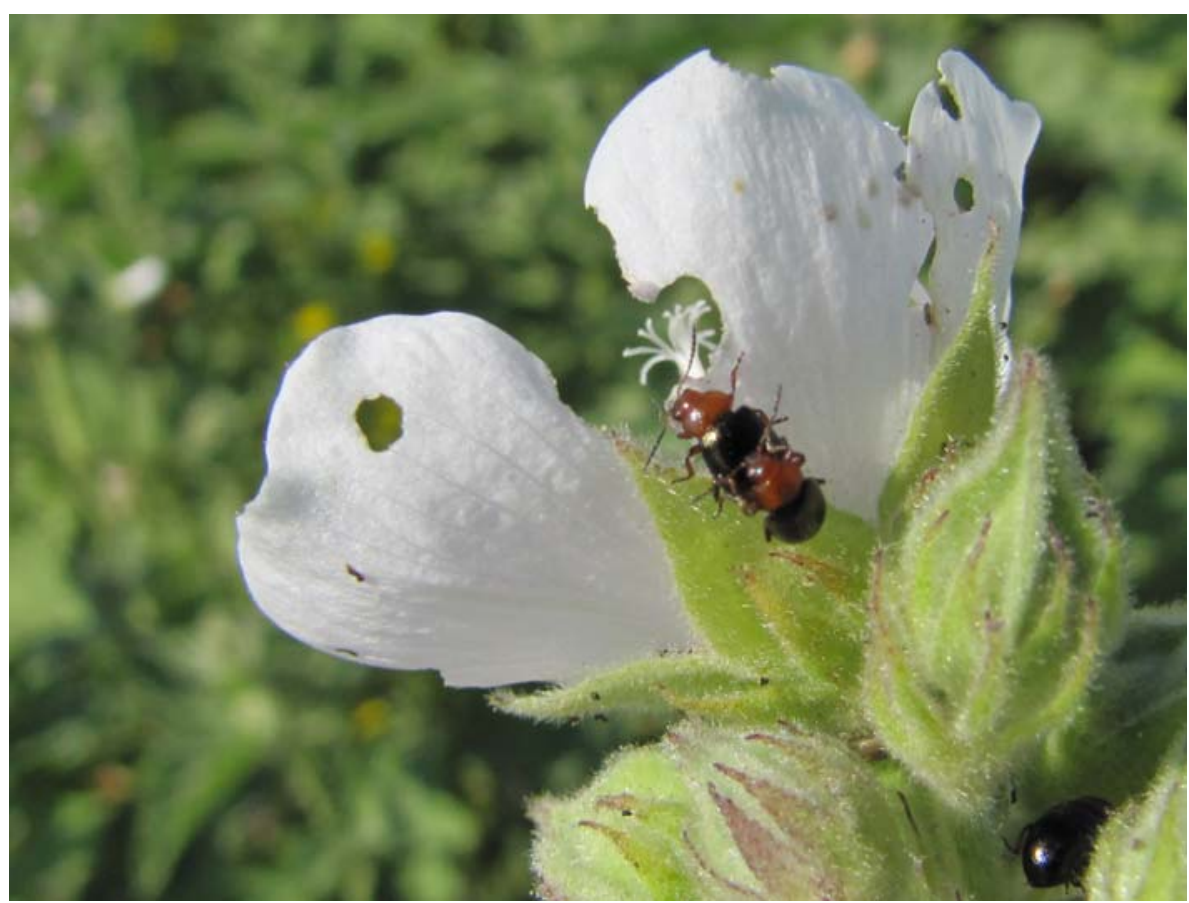

Figure 3: Damage on the flower of common marshmallow due to the feeding of Podagrica fuscicornis adults (photo by T. Bohinc)

\section{PRESENTATION OF THE SPECIES}

\subsection{Description}

We describe flea beetles as small bugs with a size from 1.5 do $4 \mathrm{~mm}$. They can jump due to the enlarged backside organ (hind legs) - Maulik's organ. They also have an ability to fly. When plant is heavily attacted by flea beetles, small round holes (up to $1 \mathrm{~mm}$ ) caused by 
an individual flea beetle's feeding may coalesce into larger areas of damage (Maceljski, 1999).

Adult beetles of Podagrica fuscicornis are 3.0 to 6.0 $\mathrm{mm}$ in size. Head and neck shield are coloured red. Front wings (sheath-wings) are dark blue to blue green and rarely are detected metal coloured. Sheath wings contain hollows which are deep, very abundant and spread scarced. Hollows on neck shield are even more compacted. Legs are characteristically yellowish to bright brownish, and upper labium is also yellow (Hubble, 2010).

\subsection{Systematics}

Flea beetles are classified into family leaf beetles (Chrysomelidae) and subfamily Alticinae (Aslan et al., 1998). In Slovenia up till now 204 species and 5 subspecies of flea beetles (Brelih et al., 2003) were detected, while on the global level more than 7000 species were described (Jolivet, 1988). In Slovenia beside Podagrica fuscicornis we are ranging in the same genus also species $P$. malvae (Illiger), $P$. menetriesi (Falderman) and P. fuscipes (F.) (Podagrica..., 2011).

\subsection{Geographical distribution}

Podagrica fuscicornis belongs to EuropeanMediterranean species group. The abundance of its populations is very large in the majority of Europe. Flea beetle is not present in Nordic countries. In Asia it occurs in Turkey and western part of Arabian Peninsula. It can be found also in Tunisia, Morocco and on Canary Islands. The abundance of this pest is from time to time also high in warmer parts of Slovenia (Brelih et al., 2003), but till now no clear evidence is noted that it would cause extensive range of damage on its host plants.

\subsection{Bionomics}

Flea beetles are insects with complete metamorphosis. Adult females lay eggs, which hatch into larvae of various shapes. After feeding and molting several times, larvae mature, pupate and later emerge as adult beetles; the length of time it takes to complete the life cycle varies greatly from species to species and is also dependent on weather and other environmental conditions (Rak Cizej et al., 2001).

Physical and chemical factors of plant defence many times have influence on the survival ability of larvae. The latter can be also affected by the appearance of natural enemies, unfavourable weather conditions,... (Rak Cizej et al., 2001).

Larvae molt three to four times and than pupate. After one to two weeks adults occur. The Chrysomelid has only one generation per year (Cmoluch, 1988). Adults overwinter usually in the soil under the grass sward, where often enough organic matter or nearby host plant are present. During overwintering they avoid exposed surfaces as arable field are (Rak Cizej et al., 2001).

\subsection{Host plants}

Very know members of genus Podagrica cause most damage on plants from family Malvaceae. Podagrica fuscicornis belongs among oligophagus herbivores and it induces damage on plants from genera Althaea, Malva and Lavatera (Neubauer et al., 1974; Cmoluch, 1988; Lecheva et al., 1996; Rotrekl, 1996; Brelih et al., 2003). Above mentioned species can cause damage also on plants from families Lamiaceae and Urticaceae (Petitpierre, 1985).

\subsubsection{Common marshmallow (Althaea officinalis L.)}

Common marshmallow or iviscus (Figure 4) is classified into family Malvaceae. The plant is perennial and soft and velvety due to a dense covering of stellate hairs and grows $2.2 \mathrm{~m}$ in height. Its origin is Europe but it can be found also in North and South America. Its natural habitats are usually moist fields, but it could be found also by the seasides and more and more it is also cultivated (Chevallier, 1996). Growers cultivate it on warmer soils. Common marshmallow is not very demanding for nutrients, it only needs deep soils and with good porosity and no rocks. It likes moisture but not standing water. We can reproduce it by seeds or vegetative with roots. Planting distance depends on which part of the plant we are aiming as a final product (Rode and Knapič, 2006). 


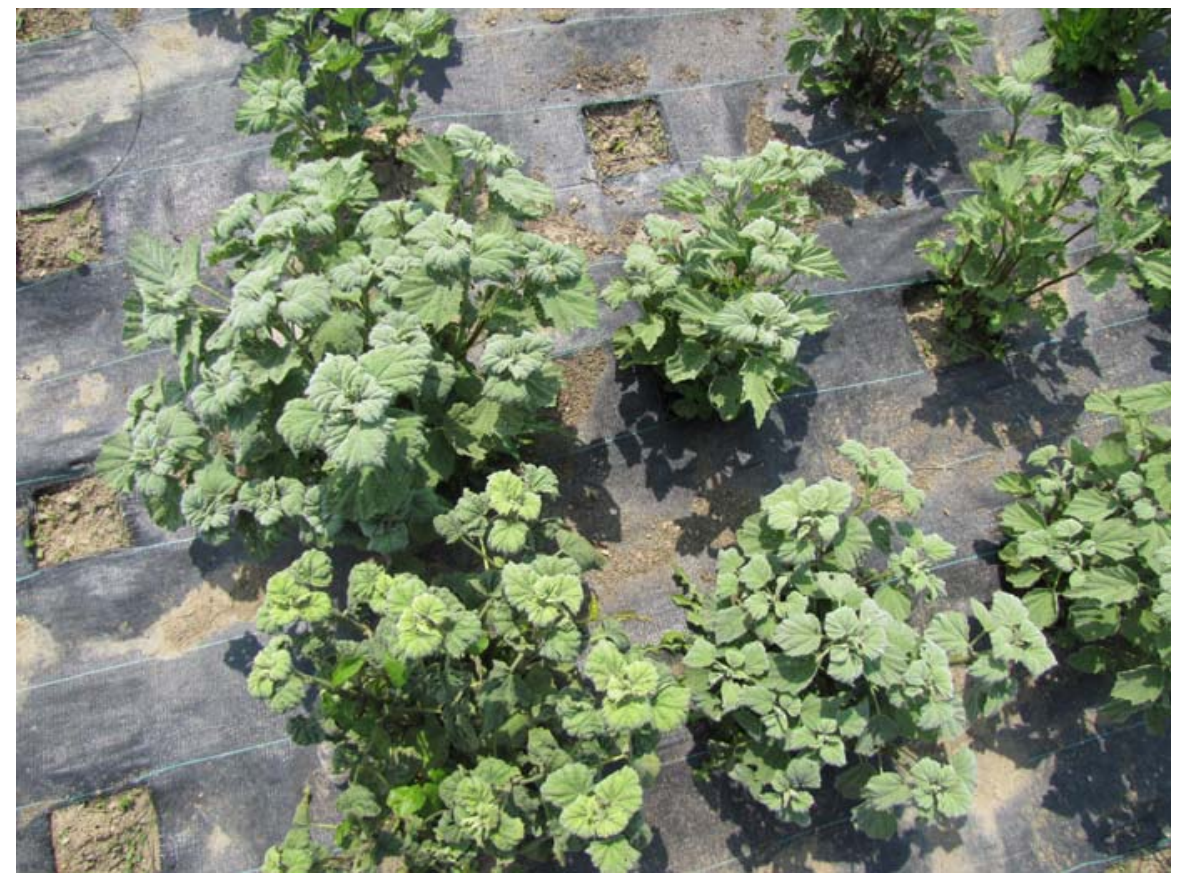

Figure 4: Plants of common marshmallow (Althaea officinalis) at the Laboratory Field of Biotechnical Faculty in Ljubljana in 2011 (photo by T. Bohinc).

Roots of common marshmallow contain $37 \%$ of starch and $11 \%$ of plant mucilage and both represent important part of herbal plant. Important medicinal parts of the plant are also leaves and flowers. Common marshmallow is used to treat infections which affect mucous membrane as its appeasing effect reassures and protects against harmful influences (Chevallier, 1996; Franova et al., 2006). It is used particularly in herbal tea mixtures (Franova et al., 2006).

\section{POTENTIAL ECONOMIC IMPORTANCE OF Podagrica fuscicornis IN SLOVENIA WITH CONCLUSIONS}

Among most important flea beetles pests in Slovenia cabbage flea beetles (Phyllotreta spp.) are placed as they can have an influence on reducing the yield of cabbage and other cultivated Brassicas (Brown et al., 2004). Also hop can be damaged and this is attribute to hop flea beetle (Psylliodes attenuatus). Important host plants of hop flea beetle are common hop plant (Humulus lupulus [L.]), common hemp (Cannabis sativa ssp. sativa var. sativa [L.]), and common nettle (Urtica dioica [L.]) (Rak Cizej and Milevoj, 2007).

The presence of $P$. fuscicornis in Slovenia for now did not represent larger danger. But in tropical and subtropical regions representative of genus Podagrica spp. regulary threaten the plant production from family Malvaceae. In this relation a permanent treath of economical reasonableness of okra production (Abelmoschus esculentum [Moench]) in Africa (Echereobia et al., 2010) is worth to mention as this species carries also viruses (Triendrébéogo et al., 2010).
Different plant species are differently adapted to drought periods. Some herbs originate from arid regions and are basically already adjusted to the shortage of moisture in the soil (Rode and Knapič, 2006). Plants of common marshmallow are described as the one which love marshy environments and are very well present all around Europe (Ross, 2001; Gardner, 2005). Global climate changes could have already in the near by future an extensive influence on greater importance of some pests, also those which harm common marshmallow. And $P$. fuscicornis could spread in the forthcoming time from warmer parts of the Europe to regions which have till now unfavourable climate factors for the occurrence of species.

In our opinion, induced extent of damage made by flee beetle presented in this paper did not influence the productivity of common marshmallow. But the abundance of up till now less known insect species warns us that changes in weather patterns and future climate changes could have influence on bionomics of the plant pests (Fuhrer, 2003; Thomson et al., 2010), 
which was not till know classified as economically important. If expecting the increase in herbal plants production, as well on domestic as broader, we must namely take into consideration also this factor.

\section{ACKNOWLEDGEMENT}

This work was carried out within Professional Tasks from the Field of Plant Protection, a program funded by the Ministry of Agriculture, Forestry, and Food of
Phytosanitary Administration of the Republic of Slovenia. We are thankful to Prof. Dea Baričevič, who informed us about the occurrence of the beetle.

\section{REFERENCES}

Aslan, I., Gruev, B., Özbek, H. 1996. A preliminary review of the subfamiliy Alticinae (Coleoptera, Chrysomelidae) in Turkey. Turk. J. Zool., 23: 373-414.

Brelih, S., Döberl, M., Drovenik, B., Pirnat, A. 2003. Gradivo za favno hroščev (Coleoptera) Slovenije. Scopolia, 50: 1279.

Brown, J., McCafferey, J. P., Brown, D. A., Harmon, B. A., Davis, J. B. 2004. Yield reduction in Brassica napus, B. rapa, B. juncea, and Sinapis alba caused by flea beetle (Phyllotreta crucifeare (Goeze) (Coleoptera: Chrysomelidae) infestation in Northern Idaho. J. Econ. Entomol., 97: 1642-1647.

Çilbiroglu, E. G., Gok, A. 2004. Flea beetles (Coleoptera: Chrysomelidae) of Isparta, Turkey, with habitat use and host plant associantions. Proc. Entomol. Soc. Wash. 106: 858-864.

Chevallier, A. 1996. Enciklopedija zdravilnih rastlin. Ljubljana, DZS: 355 p.

Cmoluch, Z. 1988. Remarks on the bionomics of Podagrica fuscicornis (Linnaeus, 1766) (Col., Chrysomelidae). Ochrona Roslin, 32: 15-16 [in Polish]

Echereobia, C. O., Okerere, C. S., Emeaso, K. C. 2010. Determination of repellence potencials of some aqueous plant extracts against okra flea beetles Podagrica uniforma. J. Biopest., 3: 505-507.

Franova, S., Nosalova, G., Mokry, J. 2006. Phytoterapy of cough. Advances in Phytomedicine, 2: 111-131.

Fuhrer, J. 2003. Agroecosystem responses to combinations of elevated $\mathrm{CO}_{2}$, ozone and global climate change. Agric. Ecosyst. Environ., 97: 1-20.

Gardner, J. A. 2005. Herbs in bloom: a guide to growing herbs as ornamental plants. Cambridge, Timber Press: 394 p.

Gruev, B. \& Döberl, M. 1997. General distribution of the flea beetles in the Palearctic subregion (Coleoptera, Chrysomelidae: Alticinae). Scopolia 27: 1-496

Jolivet, P. 1988. Food habits and food selection of Chrysomelidae. Bionomic and evolutionary perspectives. V: Jolivet, P., Petitpierre, E., Hsiao. (Eds.). Biology of Chrysomelidae. Dodrecht, Kluwer Academic Publishers: $1-24$.

Hubble, D. 2010. Key to the adults of seed and leaf beetles of the British Isles. (Coleoptera: Bruchidae, Orsodacnidae,
Megalopodidae \& Chrysomelidae). Shrewsbury, FSC. http://www.field-studies-council.org/documents/Pubs/ AIDGAP $\% 20$ test $\% 20$ version $\% 20-\% 20$ Seed $\% 20$ and $\%$ 20leaf\%20beetles.pdf (8.7.2011)

Lecheva, I., Margina, A., Zheljazkov, V. 1996. Investigation on pest entomofauna and fungus diseases on essential oil and medicinal plants in Bulgaria. Part 1. Study on the harmful entomofauna. Beitrage zur Zuchtungsforschung Bundesanstalt fur Zuchtungsforschung an Kulturpflanzen, 2: 257-260.

Maceljski, M. 1999. Poljoprivredna entomologija. Čakovec, Zrinski: 464 p.

Neubauer, S., Klimes, K., Kral, J. 1974. The most important pests of cultivated Malvaceae. Nase Liecive Rastliny, 11: 22-24.

Podagrica Chevrolat 1837. Fauna Europaea (27.1.2011). http://www.faunaeur.org/full_results.php?id=242787 (7.7.2011).

Petitpierre, E. 1985. Notas faunisticas y ecológicas sobre Chrysomelidae (Coleoptera) de Mallorca y Catalunya. Boll. Soc. Hist. Nat. Balears, 29: 31-36.

Rak Cizej, M., Milevoj, L., Gomboc, S., Döberl, M. 2001. Prve študije favne bolhačev (Coleoptera: Chrysomelidae) na območju Savinjske doline. In: Maček, Jože (ed.). $5^{\text {th }}$ Slov. Conf. Plant Prot, March 6-8 2001, Čatež ob Savi, Slovenia. Lect. and Pap., Ljubljana, Plant Prot. Soc. Slov.: 312-317.

Rak Cizej, M., Milevoj, L. 2007. Prehranske navade hroščev hmeljevega bolhača. In: Maček, Jože (ed.). $8^{\text {th }}$ Slov. Conf. Plant Prot., March 6-7 2007, Radenci, Slovenia. Lect. and Pap., Plant Prot. Soc. Slov.: 173-178.

Rode, J., Knapič, M. 2006. Namakanje zelišč. Ljubljana, Ministrstvo za kmetijstvo, gozdarstvo in prehrano: $40 \mathrm{p}$.

Ross, I. A. 2001. Medicinal plants of the world: chemical constituens, tradicional and modern medicinal uses. United States of America, Human Press: 487 p.

Rotrekl, J. 1996. Potential pests of mallow (Malva verticillata L.) and safflower (Carthamus tinctorius L.). Sbornik Vedeckych Praci - Vyzkumny Ustav Picninarsky spol. s.r.o. Troubsko, 14: 119-124.

Statitični urad RS. 2011. Popis vrtnarstva, Slovenija, 1. julij 2006. http://www.stat.si/novica_prikazi.aspx?id=510. 
Massive occurrence of Podagrica fuscicornis (L.) (Coleoptera, Chrysomelidae) on common marshmallow ...

Thomson, L. J., Macfadyen, S., Hoffman, A. A. 2010. Predicting the effects of climate change on natural enemies of agricultural pests. Biol. Control, 52:296-306.
Triendrébéogo, F., Traoré, V. S. E., Lett, J. M., Barro, N., Konaté, G., Traoré, A. S., Traoré, O. 2010. Impact of okra leaf curl disaese on morphology and yield in okra. Crop Prot., 29: 712-716. 